vertebra on the other with little vertebral displacement and with minimal involvement of the spinal cord is commonest. The only fatality at the levels $\mathrm{C} 1$ to $\mathrm{C} 3-4$ was associated with a collapse of $\mathrm{C} 3$ on $\mathrm{C} 4$ with encroachment of fragments on the spinal canal and cord compression, an injury very reminiscent of those occurring at lower levels, and indeed caused in a similar fashion and not by a sack. Below the C3-4 level the commonest injuries are overriding of one or both articular facets in a fracturedislocation or compression fracture of a vertebra, both of which encroach on the space of the spinal canal and cause serious compression and permanent damage. Thus in the upper cervical regions there is not only less displacement of the bones one on the other but a larger canal round which dislocative movements can take place.

Injury to the cervical spine occurring in porters carrying heavy loads on their heads is uncommon considering the enormous numbers of sacks that are transported in this fashion. None the less, such injuries do occur. They seem more likely to involve a higher level of the cervical region than do injuries due to other causes, and are more likely to be associated with a good rather than a poor prognosis for recovery.

\section{Summary}

In Rhodesia many heavy sacks are carried on porters' heads, yet back injuries are infrequent, only 14 cases having been seen in 10 years. Unlike most neck injuries these affect the upper rather than the lower cervical regions, and it is thought that the forces at work are more rotational than flexional.

$X$-ray studies show that when loaded with a $200-\mathrm{lb}$. $(90.7 \mathrm{~kg}$.) sack the normal cervical spine assumes a vertical position and the discs become compressed. Forward angulation occurs where the discs are weak, and may predispose to injury either at that level or in the region of compensatory hyperextension above.

The prognosis in the neck injuries largely depends on the level affected-the higher the injury the better the prognosis. This is probably because the cross-sectional area of the spinal canal is larger in the upper cervical regions, thus allowing more movement of vertebrae before the cord is involved, while the fractured vertebrae themselves show less bony displacement than when the lower levels are involved.

I wish to express my gratitude to Dr. W. M. Castle for her assistance with the statistical studies.

\section{REFERENCES}

Blockey, N. J., and Purser, D. W. (1956). F. Bone ft Surg., 38B, 794. Crandall, P. H., and Hanafee, W. N. (1964). Amer. F. Roentgenol., 92, 1260

Juhl, J. H., Miller, S. M., and Roberts, G. W. (1962). Radiology, 78,

Niemeyer, T., and Penning, L. (1963). F. Bone ft Surg., 45A, 1671

Norton, W. L. (1962), 7. Bone ft Surg., 44A, 115

Pallis, C., Jones, A. M. and Spillane, J. D. (1954), Brain, 77, 274

Payne, E. E. (1959). Neurochirurgia (Stuttg.), $1,178$.

Rogers, W. A. (1957). ₹. Bone 7t Surg., 39A, 341.

Todd, T. W., and Pyle, S. I. (1928). Amer. F. phys. Anthrop., 12, 321.

\title{
Dose of Gentamicin in Patients with Normal Renal Function and Renal Impairment
}

\author{
J. C. GINGELL,* M.B., B.CH., F.R.C.S., F.R.C.S.ED.; PAMELA M. WATERWORTH, † F.I.M.L.T.
}

Brit. med.F., 1968, 2, 19-22

Gentamicin is a broad-spectrum antibiotic belonging to the amino-glycoside group, which includes streptomycin, neomycin, and kanamycin (Weinstein et al., 1963). In-vitro studies have shown it to be bactericidal against a wide range of Grampositive and Gram-negative bacteria, including Pseudomonas aeruginosa, Proteus, and " resistant staphylococci" (Weinstein et al., 1963 ; Rubenis et al., 1963 ; Rabinovich et al., 1963 ; Barber and Waterworth, 1966). Early clinical trials in the United States of America have shown gentamicin to be most effective in the treatment of infection of the urinary tract (Bulger et al., 1963 ; Jao and Jackson, 1964 ; Klein et al., 1964). The most serious side-effect of the antibiotic is that of permanent damage to the vestibular division of the eighth nerve. In these early trials (Sweedler et al., 1963 ; Bulger et al., 1963 ; Jao and Jackson, 1964) a number of patients were rendered ataxic with an impaired sense of balance due to vestibular damage. It has since been advised by the manufacturers that a serum level of $10 \mu \mathrm{g} . / \mathrm{ml}$. should not be exceeded. As gentamicin is excreted almost entirely by glomerular filtration (Black et al., 1963) the serum and tissue levels of the antibiotic are largely dependent on renal function. If the latter is Impaired and the dosage of the drug is not reduced then abnormally high and possibly toxic levels may accumulate in the blood and tissues.

Unfortunately these early mishaps have had the effect of making us unduly cautious about this potentially valuable anti-

* Registrar, Department of Urology.

t Research Assistant, Department of Bacteriology.

Royal Postgraduate Medical School, London W.12. biotic. The usually recommended dosage of $40 \mathrm{mg}$. 12-hourly appears to be inadequate to be of any useful therapeutic value in pseudomonal infections and was the subject of a preliminary report (Darrell and Waterworth, 1967).

As the therapeutic index of the antibiotic is narrow, great care has to be exercised in the size of dose and frequency of administration. This is particularly evident in patients with impaired renal function who are often the most likely to benefit from its use in the treatment of resistant urinary infections. We have therefore recorded the serum levels obtained in normal subjects and non-uraemic and uraemic patients receiving gentamicin in order to gain more information regarding dosage.

\section{Material and Methods}

A single intramuscular injection of $80 \mathrm{mg}$. of gentamicin was given to volunteers with normal renal function. Blood was taken for measurement of serum levels at half, one, two, three, six, and eight hours after administration. The same dose was also given to patients undergoing intermittent haemodialysis and to patients undergoing dietary management of chronic renal failure. Serum levels were determined in this group at intervals up to 72 hours after injection. Further serum levels were obtained from patients with varying degrees of renal impairment undergoing treatment with gentamicin for resistant urinary tract infections. In this latter group peak and trough serum levels after repeated administration were taken to ensure that there was no tendency to accumulation to toxic 
levels. The sex, age, and weight of all patients were recorded. Renal function was assessed by the glomerular filtration rate (G.F.R.) as measured by endogenous creatinine clearance and the blood urea was recorded. Gentamicin serum assays were performed by the vertical diffusion technique of Mitchison and Spicer (1949) using the Oxford staphylococcus.

\section{Results}

The average peak serum level obtained after $80 \mathrm{mg}$. of gentamicin intramuscularly was $7.0 \mu \mathrm{g} . / \mathrm{ml}$. (range 4.2 to 12 $\mu$ g./ml.) (Table I). The peak serum level is attained between half and two hours after injection and there is a rapid fall in

TABLE I.-Peak Serum Levels of Gentamicin after a Single Injection of

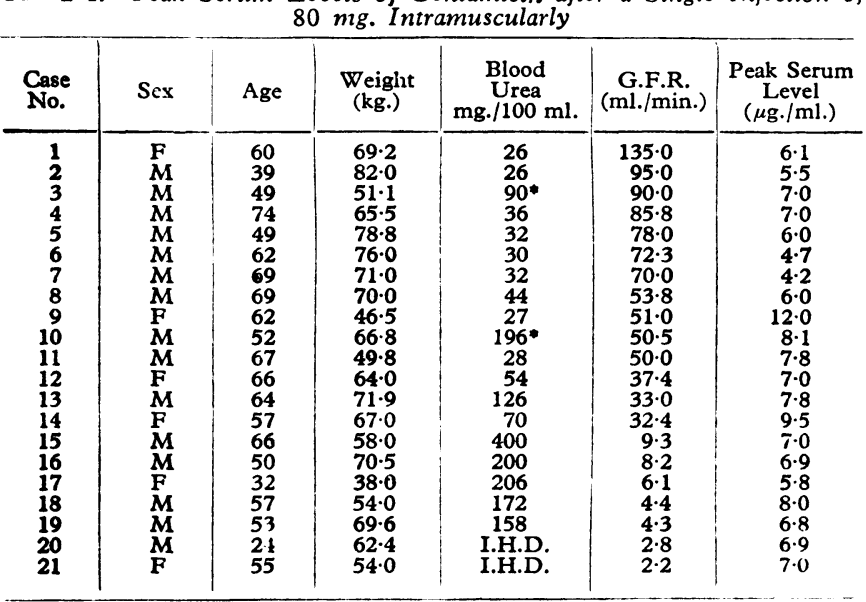

Average $=7 \cdot 0 \mu \mathrm{g} . / \mathrm{ml}$.

Range (4.2-12 $\mu \mathrm{g} . / \mathrm{ml}$.)

I.H.D. = intermittent haemodialysis.

the serum level after this period in the presence of normal renal function (G.F.R. $>70 \mathrm{ml} . / \mathrm{min}$.) (Fig. 1). At eight hours there is approximately only $1 \mu \mathrm{g} . / \mathrm{ml}$. remaining in circulation.

From Table I it can be seen that there is no marked difference between the peaks obtained in patients with normal renal function and those with severe renal impairment, including patients maintained on intermittent haemodialysis.

The serum levels attained after $80 \mathrm{mg}$. of gentamicin intramuscularly in two patients with moderate impairment of renal function are shown in Fig. 2, there being over $2 \mu \mathrm{g} . / \mathrm{ml}$. still

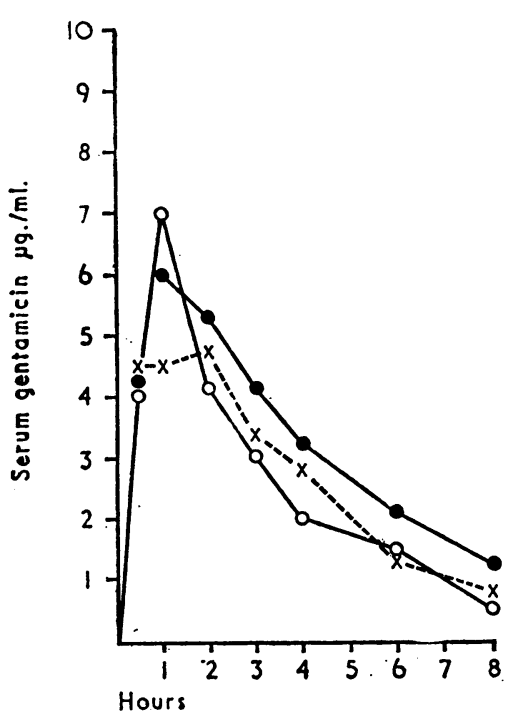
mg. intramuscularly (Cases 4,5 , and 6 , Table I).
Fig. 1.- Serum gentamicin levels in three cases with normal renal function after 80 tions. As the disappearance of gentamicin from the blood stream occurs in an exponential manner, the serum half-life was obtained in each case by plotting the serum levels on semi-log paper. The results are shown in Table II. The serum half-life and glomerular filtration rate in each subject were then correlated by plotting the data on $\log / \log$ paper as described by Sørenen et al. (1967) for kanamycin. Fig. 4 shows the regression line relating $\mathrm{T}_{2}^{\frac{1}{2}}$ to glomerular filtration rate together with the $95 \%$ confidence limits for an individual patient. With the graph thus obtained it is possible, knowing the patient's glomerular

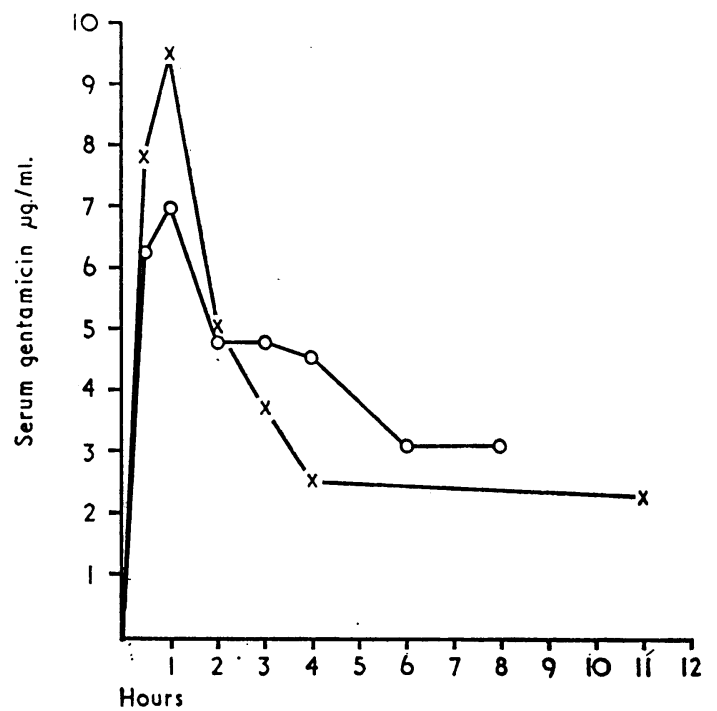

Fig. 2.- Serum gentamicin levels in two cases with moderate renal impairment (Cases 12 and 14, Table I).

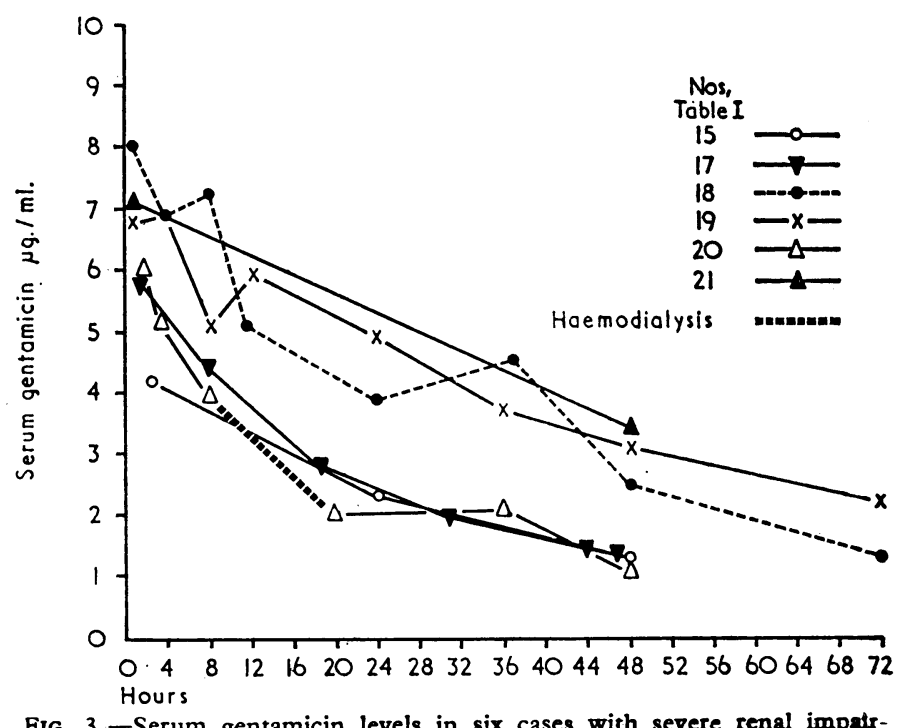

FIG. 3. - Serum gentamicin levels in six cases with severe renal impatrment after $80 \mathrm{mg}$. intramuscularly.

TABLE II.-Calculated Serum Half-life $\left(T \frac{1}{2}\right)$ of Gentamicin and GlomeruTABLE II.-Calculated Serum Half-life
lar Filtration Rate (G.F.R.) in 18 Subjects

\begin{tabular}{|c|c|c|c|c|c|}
\hline Case No. & $\begin{array}{c}\text { G.F.R. } \\
\text { (mi./min.) }\end{array}$ & $\begin{array}{c}\mathrm{T} \\
\text { (Hours) }\end{array}$ & Case No. & $\underset{\text { (mi./min.) }}{\text { G.F.R. }}$ & $\begin{array}{c}\text { Tł } \\
\text { (Hours) }\end{array}$ \\
\hline $\begin{array}{r}2 \\
4 \\
5 \\
7 \\
* \\
8 \\
10 \\
12\end{array}$ & $\begin{array}{l}95 \cdot 0 \\
85.8 \\
78 \cdot 0 \\
70 \cdot 0 \\
62 \cdot 3 \\
60 \cdot 4 \\
53 \cdot 8 \\
50 \cdot 5 \\
37 \cdot 4\end{array}$ & $\begin{array}{l}2.5 \\
2.1 \\
3.1 \\
3.5 \\
2.3 \\
2.8 \\
3.4 \\
5.7 \\
4.1\end{array}$ & $\begin{array}{r}13 \\
14 \\
15 \\
16 \\
17 \\
18 \\
19 \\
21\end{array}$ & $\begin{array}{r}33 \cdot 0 \\
32 \cdot 4 \\
30.8 \\
9 \cdot 3 \\
8 \cdot 2 \\
6.1 \\
4.4 \\
4 \cdot 3 \\
2 \cdot 2\end{array}$ & $\begin{array}{r}5.7 \\
4.6 \\
4.2 \\
26.8 \\
10.4 \\
21.6 \\
29.0 \\
39.0 \\
45.2\end{array}$ \\
\hline
\end{tabular}
patients studied in whom there were a sufficient number of serum level determina- 
filtration rate, to predict the $T \frac{1}{2}$. Having determined the $T \frac{1}{2}$ one is able to predict the serum levels that will be obtained after an $80-\mathrm{mg}$. dose if a peak level of $7.0 \mu \mathrm{g} . / \mathrm{ml}$. (the average value; see Table $I$ ) is assumed. The accuracy of prediction in a given case with this method is shown in Fig. 5. The patient had a glomerular filtration rate of $6.1 \mathrm{ml} . / \mathrm{min}$. and from Fig. 4 the serum half-life of gentamicin was calculated to be 22 hours. The patient received $80 \mathrm{mg}$. of gentamicin intramuscularly at 48-hour intervals on the basis of the predicted serum levels. During the first four days of treatment serum levels were determined and were shown to correspond reasonably closely to the levels that were predicted. In this way we bave been able to plan dosage in the presence of renal impairment.

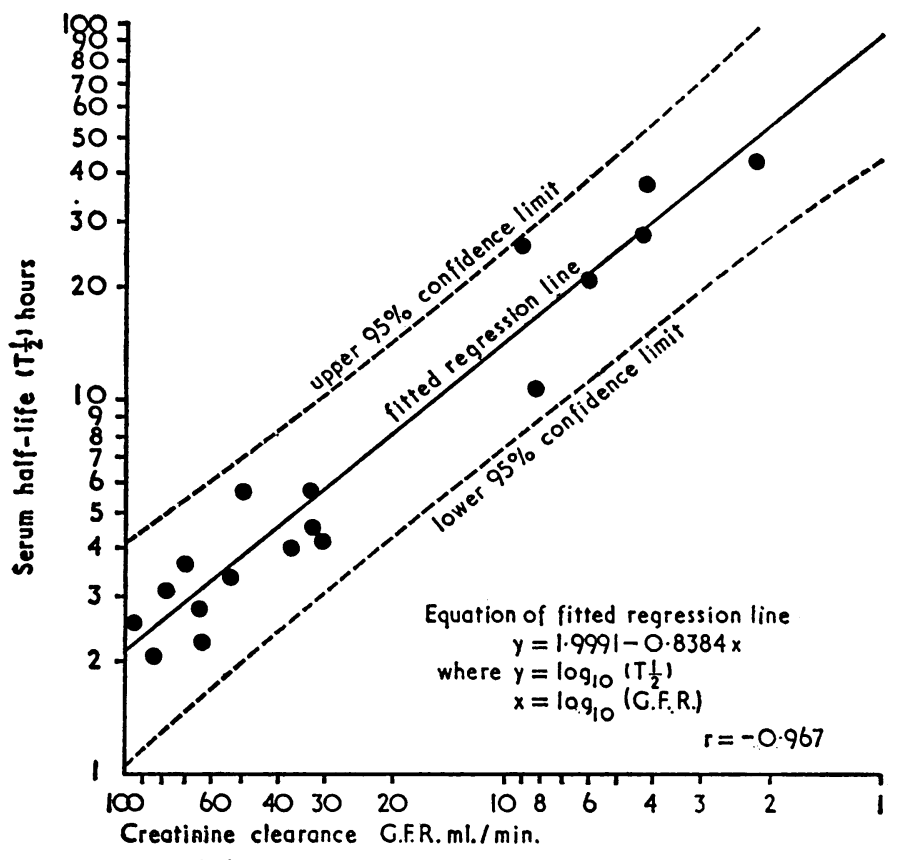

Pio. 4.-Correlation between glomerular filtration rate (G.F.R.) and serum balf-life $\left(\mathrm{T} \frac{1}{2}\right)$ of gentamicin in 18 subjects.

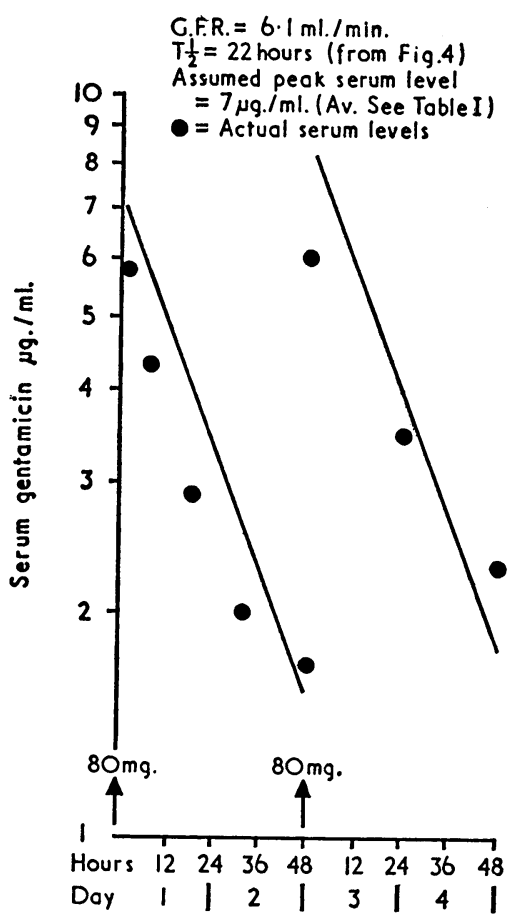

FIG. 5.-Predicted and actual serum gentamicin levels in a patient receiving $80 \mathrm{mg}$. intramuscularly at 48 -hour intervals.

\section{Discussion}

It has been observed that after $40 \mathrm{mg}$. of gentamicin intramuscularly in three subjects with normal renal function the highest peak serum level obtained was only $4.1 \mu \mathrm{g} . / \mathrm{ml}$. (Darrell and Waterworth, 1967). As the minimum inhibitory concentration of gentamicin for Ps. aeruginosa is $4 \mu \mathrm{g} . / \mathrm{ml}$. or more, the recommended dose of $40 \mathrm{mg}$. 12-hourly is clearly inadequate for the treatment of infections with this organism. A more satisfactory peak serum level is obtained after an intramuscular dose of $80 \mathrm{mg}$. (Table I).

It has been shown that there is a rapid equilibration between the serum level of gentamicin and that attained in the renal lymphatics, and hence the renal parenchyma, shortly after intramuscular injection in dogs (Chisholm et al., 1968). For effective treatment adequate serum levels, and therefore tissue levels, must be maintained in urinary tract infections where there is renal parenchymal involvement and also for infections outside the urinary tract. Owing to the rapid excretion of the antibiotic in the presence of normal renal function (Fig. 1) a dose interval of eight hours is advised, and not 12 hours as recommended at present by the manufacturers.

The peak serum levels obtained after a single dose of 80 mg. intramuscularly in patients with renal impairment are comparable to those obtained in normal subjects (Table I). Curtis et al. (1967) found that higher serum levels were attained in three patients on intermittent haemodialysis than in two normal subjects 10 minutes after aciministration of gentamicin by the intravenous route. Our observations lead us to suggest that in the treatment of infections in patients with impaired renal function the same initial dose of $80 \mathrm{mg}$. intramuscularly should be given as in those patienis with normal renal function.

As gentamicin is excreted almost entirely by glomerular filtration the rate of clearance from the blood stream is therefore slower in renal failure, and this has important implications in determining the frequency of administration. We have used the information obtained by correlating the glomerular filtration rate and the serum half-life of the antibiotic in 18 patients studied (Fig. 4) to plan a scheme of dosage based on the glomerular filtration rate. In this way we have avoided too frequent administration, and hence accumulation and toxicity, and underdosage with the risk of encouraging the development of bacterial resistance. Serian levels taken during therapy have demonstrated a close correlation between the actual and predicted levels.

It is, of course, not always possible to have the glomerular filtration rate available when treatment needs to be started, but usually a blood urea will have been obtained. From the results presented, and from the additional information given by serum levels obtained during therapy, we have formulated an approximate scheme of dosage (Table III). The scheme outlined does

TABLE III.-Approximate Scheme of Dosage for Gentamicin

\begin{tabular}{|c|c|c|}
\hline $\begin{array}{c}\text { Blood Urea } \\
\text { (mg./100 ml.) }\end{array}$ & $\begin{array}{l}\text { Creatinine Clearance } \\
\text { (G.F.R.) (ml./min.) }\end{array}$ & $\begin{array}{l}\text { Dose and Frequency } \\
\text { of Administration }\end{array}$ \\
\hline \multirow{2}{*}{$\begin{array}{c}<35 \\
50-100 \\
>200 \\
\text { Twice weekly intermittent } \\
\text { haemodialysis }\end{array}$} & $\begin{array}{r}>70 \\
30-50 \\
5-10\end{array}$ & $\begin{array}{l}80 \mathrm{mg} \cdot{ }^{*} \text { 8-hourly } \\
80 \mathrm{mg} .12 \text {-hourly } \\
80 \mathrm{mg} . \text { every } 48 \text { hours }\end{array}$ \\
\hline & $<3$ & $80 \mathrm{mg}$. after dialysis \\
\hline
\end{tabular}

not cover all degrees of renal impairment and is therefore incomplete ; it does, however, provide a useful guide to therapy in the groups defined. Repeated peak and trough serum levels during therapy with gentamicin in the patients studied have shown no accumulation to toxic levels with the increased dose regimen in the manner described. It is advised that the degree of renal functional impairment should be determined as accurately as possible and the progress of treatment checked by determining serum levels. Renal function may improve under successful treatment when there is renal parenchymal involve- 
ment, and a revision of dosage then becomes necessary. Modification of dosage in renal failure is more practical for routine hospital use if only the interval between doses is altered as outlined in Table III. It is, however, feasible to use a smaller dose of 60 or $40 \mathrm{mg}$. at more frequent intervals after the initial loading dose of $80 \mathrm{mg}$. to maintain a therapeutic serum level.

In only one instance have there been any observed toxic sideeffects. These occurred in a woman (Case 9, Table I) who one hour after a single $80-\mathrm{mg}$. injection complained of marked giddiness. The symptoms were associated with a peak serum level of $12 \mu \mathrm{g} . / \mathrm{ml}$., the highest in the series, and persisted for one and a half hours. We have not administered gentamicin on a body-weight basis but have used the more simple and practical method of giving $80 \mathrm{mg}$. (2-ml. phial) at suitable intervals, depending on renal function. There is, however, a negative correlation between body weight and peak serum level in the patients studied which is statistically significant at the $5 \%$ level. In view of the high peak level attained in the one subject described, who weighed only $46.5 \mathrm{~kg}$., we now use a $60-\mathrm{mg}$. dose in patients weighing less than $60 \mathrm{~kg}$.

The present study is part of a clinical investigation of gentamicin in resistant urinary tract infections, including Ps. aeruginosa, which is still in progress. This study includes pretreatment and post-treatment vestibulometry to assess toxicity, and to date there have been no recorded untoward sequelae of treatment with the increased dose regimen described.

\section{Summary}

Serum levels of gentamicin have been determined in normal subjects and in patients with renal impairment after $80 \mathrm{mg}$. intramuscularly. The average peak serum level obtained was $7.0 \mu \mathrm{g} . / \mathrm{ml}$., which is independent of renal function, assessed by endogenous creatinine clearance. In the presence of normal renal function there was a rapid fall in the serum level to approximately $1 \mu \mathrm{g} . / \mathrm{ml}$. at eight hours, and it is advised that gentamicin be given at eight-hourly intervals. The glomerular filtration rate (endogenous creatinine clearance) and the serum half-life of gentamicin have been correlated in 18 subjects. This has enabled the formulation of a dose schedule in patients with impaired renal function based on the glomerular filtration rate. It is suggested that in renal failure the interval between doses should be lengthened, and an approximate scheme of dosage is presented.

ADDENDUM.-British Schering Limited, the suppliers of gentamicin, have recently recommended that the antibotic be administered eight-hourly and not 12-hourly to patients with normal renal function.

We are grateful to Professor L. P. Garrod for his advice in the conduct of this investigation and for his helpful criticism in the preparation of the paper. We wish also to thank Professor Ralph Shackman for permission to study these patients, who were under his care. The gentamicin was supplied by British Schering Limited.

\section{REFERENCES} Barber, Mary, and Waterworth, Pamela M. (1966). Brit. med. f., 1, 203.
Black, J., Calesnick, B., Williams, D., and Weinstein, M. J. (1963). Black, J., Calesnick, B., Williams, D., and Weinstein,

Bulger, R. J., Sidell, S., and Kirby, W. M. M. (1963). Ann. intern. Med., 59, 593.

Chisholm, G. D., Calnan, J. S., Waterworth, P. M., and Reis, N. D. (1968). Brit. med. F. In press.

Curtis, J. R., McDonald, S. J., and Weston, J. H. (1967). Brit. med. f., 2, 537.

. (1967). Brit. med. F., 2, 535. Jao, R. L., and Jackson, G. G. (1964). 7. Amer. med. Ass., 189, 817 lein, J. O., Eickhoff, T. C., and Finland, M. (1964). Amer. F. med. Mitchison, 248, 528.

Mitchison, D. A., and Spicer, C. C. (1949). F. gen. Microbiol., 3, 184 (1963). Antimicrobial

Agents and Chemotherapy, p. 164.
Rubenis, Mary, Kozii, Vera M., and Jackson, G. G. (1963). Antimicrobial Agents and Chemotherapy, p. 153.

Sørenen, A. W. S., Szabo, L., Pedersen, A., and Scharff, A. (1967) Postgrad. med.' f., 43, May Suppl., p. 37 .

Sweedler, D. R., Gravenkemper, C. F., Bulger, R. J., Brodie, Jean L. and Kirby, W. M. M. (1963). Antimicrobial Agents and Chemotherapy, p. 157.

Weinstein, M. J., Luedemann, G. M., Oden, E. M., and Wagman, G. H. (1963). Antimicrobial Agents and Chemotherapy, p. 1.

\title{
Distribution of Gentamicin in Body Fluids
}

\author{
G. D. CHISHOLM,* CH.M., F.R.C.S., F.R.C.S.ED. ; J. S. CALNAN, $\dagger$ M.R.C.P., F.R.C.S. \\ PAMELA M. WATERWORTH, $\ddagger$ F.I.M.L.T. ; N. D. REIS,§ F.R.C.S.
}

Brit. med. F., 1968, 2, 22-24

The clinical value of an antibiotic depends on an effective concentration reaching the sites of infection. A urinary infection may seem to respond to an antibiotic by its ability to sterilize the urine, yet chronic pyelonephritis may still develop in later years. Close follow-up is essential to detect a recurrence of the urinary infection (Garrod et al., 1954) even though there may be no symptoms referable to the urinary tract (Kleeman et al., 1960). This anomaly is generally explained by the failure of the antibiotic to treat foci of infection in the renal parenchyma effectively. The concentration of any antibiotic or chemotherapeutic agent in the renal parenchyma may therefore be of considerable importance in the assessment of its effectiveness in the treatment of urinary tract infection (Schlegel, 1962 ; Katz et al., 1964 ; Jameson, 1965).

\footnotetext{
* Consultant Urological Surgeon, Hammersmith Hospital and Royal Postgraduate Medical School, London $\mathbb{W} .12$.

t Reader in Plastic Surgery, Hammersmith Hospital and Royal Postgraduate Medical School, London W.12.

$\ddagger$ Research Assistant, Hammersmith Hospital and Royal Postgraduate Medical School, London W.12.

$\checkmark$ Research Fellow, Hammersmith Hospital and Royal Postgraduate Medical School, London W.12.
}

The clinical value of gentamicin in the treatment of a urinary tract infection has been shown in patients with either normal or impaired renal function (Bulger et al., 1963; Jao and Jackson, 1964). This antibiotic is of particular value against Pseudomonas aeruginosa and Proteus and resistant strains of Staphylococcus aureus (Barber and Waterworth, 1966). The present studies were made in order to measure the rate of distribution and excretion of gentamicin in the body fluids of the normal dog.

\section{Materials and Methods}

Fifteen greyhounds, each weighing 20-30 kg., were studied in two groups. When samples of blood and urine were required the unanaesthetized animal remained in a Pavlov stand. When lymph as well as blood and urine samples were required, the animal was anaesthetized with sodium pentobarbitone and maintained on oxygen and nitrous oxide. Lymph was obtained from the thoracic duct, which was exposed through a neck incision and cannulated with fine polyethylene tubing $(1 \mathrm{~mm}$. 